\title{
Peningkatan kemampuan berhitung melalui permainan Congklak modifikasi
}

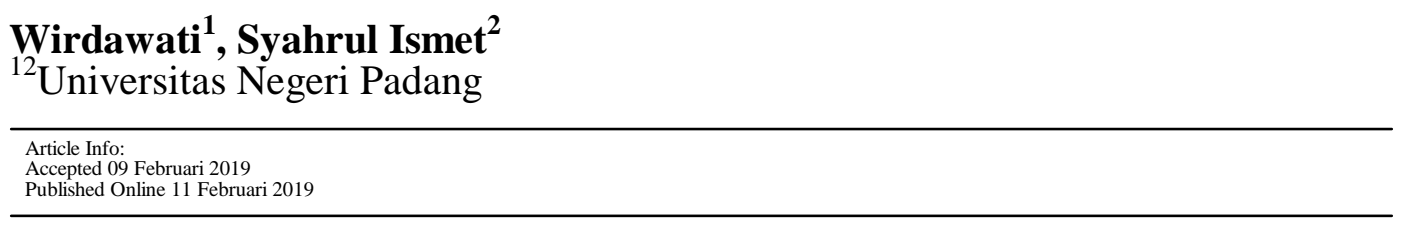

\begin{abstract}
This study aims to determine the improvement of children's numeracy skills through modified congklak games. The type of research used is classroom action research (CAR). The research subjects were 15 students of the Generation of West Pasaman Kindergarten. The time used in this study was 2 months, from July to August 2018. The study was conducted in 2 cycles. Data collection is done by observation and documentation study. Data were analyzed by percentage techniques. The results of the study on the implementation of the first cycle of the first meeting until the third meeting showed an increase in numeracy skills in children. After the second cycle of the first meeting until the third meeting, there was an increase in the numeracy skills of children, especially in counting 1-10, distinguishing the concept of many and few and summing up simply. After being given action on sikulus I and cycle II, it can be concluded that the ability of child counting can be improved by a haughty game of modification.y of child counting can be improved by a haughty game of modification.
\end{abstract}

Keyword: Counting ability, game congklak modification

This is an open access article distributed under the Creative Commons Attribution License, which permits unrestricted use,
distribution, and reproduction in any medium, provided the original work is properly cited. 02018 by author

\section{PENDAHULUAN}

Anak usia dini merupakan individu yang sedang atau akan menjalani suatu proses pertumbuhan dan perkembangan yang pesat dan menjadi fundamental bagi perkembangan selanjutnya. Anak usia dini adalah anak yang berada dalam rentang usia 0-6 tahun hingga bisa menyelesaian pendidikan di Taman Kanak-Kanak. Taman kanakkanak adalah pendidikan anak usia dini pada jalur normal. Pendidikan taman kanak-kanak bertujuan membantu anak didik mengembangkan berbagai potensi baik psikis dan fisik yang meliputi moral dan nilai-nilai agama,sosial, emosional, kognitif, bahasa, fisik motorik kemandirian dan seni untuk mempersiapkan memasuki pendidikan dasar.

Pada proses belajar mengajar terdapat beberapa aspek perkembangan anak yang perlu dikembangkan yaitu Nilai Agama dan Moral, Fisik, Kognitif, Bahasa dan Sosial Emosional (Syaodih, E., \& Agustin, M, 2014). Salah satu aspek perkembangan yang berkembang sangat pesat adalah perkembangan kognitif. Proses kognitif adalah proses manusia memperoleh pengetahuan tentang dunia, yang meliputi proses berpikir, belajar, menangkap, mengingat dan memahami (Srianis, K., Suarni, N. K., Ujianti, P. R., \& Psi, S, 2014).

Pendidikan Taman Kanak-kanak merupakan salah satu bentuk pendidikan anak usia dini dengan prinsip bermain seraya belajar, dengan pemahaman bahwa dunia anak merupakan dunia bermain, anak belajar melalui permainan atau bermain. di Taman kanak-kanak (TK), permainan atau bermain, membuat anak senang melakukan berbagai aktivitas, dari aktivitas yang dilakukananak-anak berlatih dan memperoleh pengalaman yang akan membentuk pengetahuan dan kemampuannya.

Tujuan pendidikan anak usia dini adalah mengembangkan berbagai potensi anak sejak dini sebagai persiapan untuk hidup dan dapat menyesuaikan diri dengan lingkungan sekitarnya, sehingga dapat mengembangkan beberapa aspek-aspek perkembangan anak meliputi aspek moral dan nilai-nilai agama, sosial, emosional, kemandirian, bahasa, kognitif, fisik-motorik dan seni. Bermain merupakan alat yang paling kuat untuk membelajarkan kemampuan berbahasa anak dengan cara berkomunikasi. Melalui komunikasi inilah anak dapat menyampaikan maksud maupun perasaannya.

Berdasarkan hasil pengamatan awal di Taman Kanak-Kanak Generasi Bunda Kecamatan Luhak Nan Duo dapat diketahui bahwa kemampuan mengenal bentuk geometri masih rendah. Anak-anak belum menguasai bentuk geometri 
dengan baik. Hal itu dibuktikan dengan masih adanya anak yang kebingungan dalam menyebutkan macam-macam bentuk segi empat, segitiga, dan lingkaran. Rendahnya kemampuan mengenal geometri pada anak disebabkan oleh penggunaan media pembelajaran yang terbatas oleh guru. Guru hanya mengenalkan dua macam bentuk geometri yaitu bentuk segi empat dan lingkaran dengan metode ceramah dengan memanfaatkan media papan tulis dan gambar. Guru hanya menceritakn gambar bentuk geometri tersebut didepan kelas. Sedangkan tidak semua anak mendegarkan apa yang sedang dicerikan oleh guru.

Media pembelajaran pada tingkat Taman Kanak-Kanak sangat diperlukan pada saat proses belajar mengajar, karena dunia anak merupakan dunia bermain, maka dari itu pembelajaran yang ada di Taman Kanak-Kanak seharusnya diarahkan dengan cara bermain sambil belajar yang dikemas dengan menarik. Kegitan mengembangkan kemampuan berhitung pada anak-anak dapat dilakukan dengan berbagai hal, salah satunya dengan menggunakan.

Berdasarkan uraian diatas, maka penulis tertarik melakukan penelitian tindakan kelas dengan judul Peningkatan Kemampuan Berhitung Melalui permainan Congklak Biji Sawit di Taman Kanak-kanak Generasi Bunda Kecamatan Luhak Nan Duo Pasaman Barat.

\section{METODE}

Penelitian yang digunakan adalah penelitian tindakan kelas (classroom action research). Menurut Arikunto (2006) penelitian tindakan kelas yaitu suatu penelitian yang mengkaji tentang bagaimana sifat reflektif oleh orang yang melakukan tindakan. Penelitian tindakan kelas ini merupakan sebuah kegiatan memperbaiki proses mengajar guru dan mengembangkan kemampuan profesional secara sistematis.

Penelitian dilaksanakan di Taman Kanak-kanak Generasi Bunda Pasaman Barat. Penelitian berlangsung pada Juli-Agustus 2018 pada semester ganjil tahun pelajaran 2018/2019. Subjek penelitian penelitian ini adalah 15 siswa TK generasi bunda pasaman barat pada kelompok B. Peneliti mengambil subjek penelitian di TK ini yaitu dikarenakan masih banyak anak TK yang kemampuan mengenal bilangan belum sesuai dengan yang diharapkan disebabkan karena kemampuan anak mengenal bilangan, membedakan kosep banyak sedikit dan menjumlah bilangan sederhanas belum berkembang optimal.

Menurut pendapat Arikunto, dkk (2016) "Penelitian akan dilaksanakan dengan dua siklus. Seandainya siklus pertama tidak berhasil maka selanjutnya akan diberikan tindakan dengan siklus kedua. Setiap siklus dilaksanakan pertemuan sebanyak tiga kali. Adapun tahap dalam penelitian ini adalah perencanaan, pelaksanaan, pengamatan dan refleksi. Data yang diperoleh selama penelitian kemudian diolah dengan teknik persentase (Haryadi, 2009).

\section{HASIL PENELITIAN}

Hasil observasi peningkatan kemampuan berhitung anak berdasarkan hasil siklus I dan siklus II adapat dilihat pada tabel berikut :

Tabel 1. Hasil Observasi Peningkatan Kemampuan Berhitung Melalui Permainan Congklak Modifikasi

\begin{tabular}{|c|c|c|c|c|c|}
\hline$\overline{\mathrm{No}}$ & Aspek yang dinilai & $\begin{array}{c}\text { Kondisi Awal } \\
(\%)\end{array}$ & $\begin{array}{l}\text { Siklus I } \\
(\%)\end{array}$ & Siklus II (\%) & Keterangan \\
\hline 1 & $\begin{array}{l}\text { Anak mampu menyebutkan urutan } 1- \\
10 \text { dalam permainan congklak } \\
\text { modifikasi }\end{array}$ & 0 & 12,5 & 93,75 & Meningkat \\
\hline 2 & $\begin{array}{l}\text { Anak mampu membedakan konsep } \\
\text { banyak sedikit dalam permainan } \\
\text { congklak modifikasi }\end{array}$ & 0 & 18,75 & 87,5 & Meningkat \\
\hline 3 & $\begin{array}{l}\text { Anak mampu menjumlah dalam } \\
\text { permainan congklak modifikasi }\end{array}$ & 0 & 12,5 & 81,25 & Meningkat \\
\hline
\end{tabular}

Dari table di atas dapat kita pelajari bahwa nilai KKM sudah dapat dicapai oleh anak pada semua aspek yang diteliti yaitu 93,75\% pada aspek pertama 1, 87,5\% pada aspek kedua, dan 81,25\% pada aspek ketiga. Supaya lebih jelas peningkatan kemampuan mengenal bilangan dapat kita lihat pada grafik berikut : 


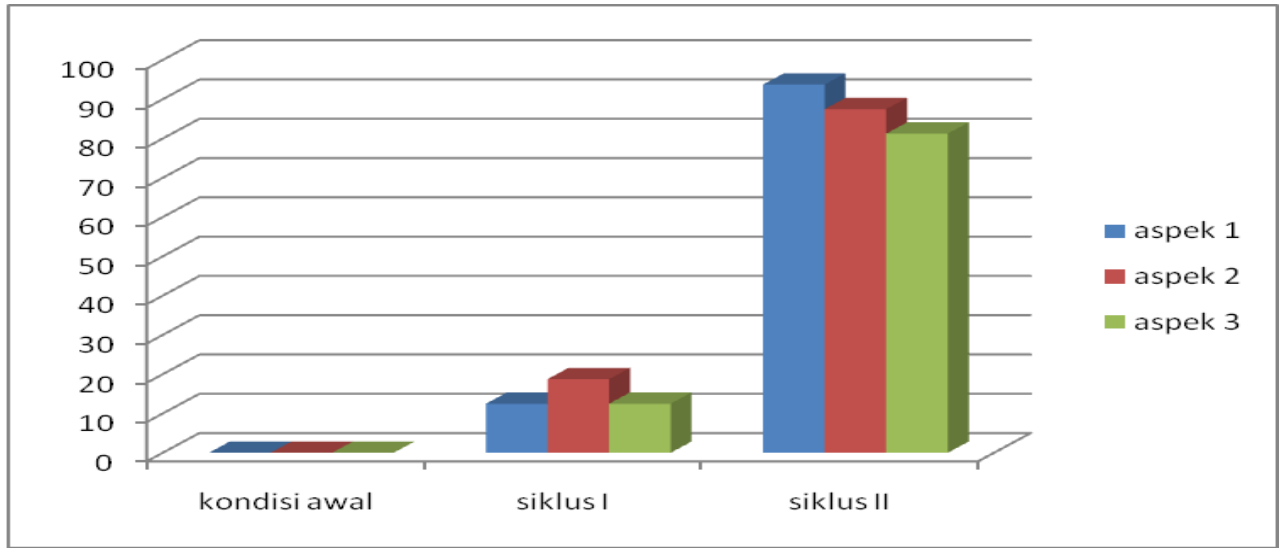

Grafik 1. Hasil Observasi Peningkatan Kemampuan Berhitung melalui Permainan Congklak Modifikasi

\section{PEMBAHASAN}

Hasil observasi awal pada siklus pertama menunjukkan bahwa kemampuan berhitung anak meningkat. Hasil kondisi awal pada penelitian ini diketahui bahwa pada aspek pertama, anak yang mendapatkan nilai berkembang sangat baik (BSB) sebesar 0\%. Keadaan ini meningkat pada hasil siklus I yaitu $12,5 \%$ dan meningkat di siklus II menjadi 93,75\%. Aspek kedua, pada kondisi awal tidak ada yang mendapatkan nilai berkembang sangat baik (BSB) atau $0 \%$, meningkat di siklus I menjadi $18,75 \%$ dan meningkat menjadi $87,5 \%$ pada siklus II. Aspek ketiga, pada kondisi awal tidak ada yang mendapatkan nilai berkembang sangat baik (BSB), meningkat menjadi $12,5 \%$ pada siklus I dan meningkat menjadi $81,25 \%$ pada siklus II.

UU RI No.20 Tahun 2003 tentang SISDIKNAS pasal 1 ayat 14 menyatakan, " Pendidikan anak usia dini adalah suatu upaya pembinaan yang ditujukan kepada anak sejak lahir sampai anak berusia enam tahun yang dilakukan melalui pemberian rangsangan pendidikan untuk membantu pertumbuhan dan perkembangan jasmani dan rohani agar anak memiliki kesiapan dalam memasuki pendidikan lebih lanjut."

Menurut Suryana (2013) tujuan pendidikan memuat gambaran tentang nilai-nilai yang baik, luhur, pantas, benar dan indah untuk kehidupan. Tujuan pendidikan memiliki dua fungsi yaitu memberikan arah kepada segenap kegiatan pendidikan dan merupakan sesuatu yang ingin dicapai oleh segenap kegiatan pendidikan. Sebagai suatu komponen pendidikan, tujuan pendidikan memiliki posisi yang penting diantara komponen-komponen pendidikan lainnya. Pendidikan anak usia dini bertujuan untuk membangun landasan bagi berkembangnya potensi anak agar menjadi manusia yang beriman dan bertakwa kepada Tuhan Yang Maha Esa (Ahmad Susanto, M. P, 2016).

Menurut Wahyudi (2014), cara pembelajaran matematika pada anak dapat dilakukan dengan: 1) Pembelajaran naturalis,yaitu pembelajaran yang diberikan dalam lingkungan yang terencana baik di rumah maupun di sekolah;2) Pengalaman, yaitu pembelajaran formal yang diprakarsai oleh orang dewasa; 3) Pengalaman pembelajaran struktural, yaitu aktivitas pembelajaran terencana.

Berdasarkan hasil penelitian diketahui bahwa permainan congklak modifikasi mampu meningkatkan disiplin anak, anak bersikap lebih tertib dan mampu meningkatkan kemampuan berhitung anak. Permainan congklak yang dilaksanakan mampu menarik perhatian anak karena media yang digunakan sudah dimodifikasi dengan berbagai bentuk dan berbagi warna.

Hasil penelitian ini sesuai dengan penelitian yang dilakukan oleh Ramaini (2010) tentang Peningkatan Kemampuan Berhitung Melalui Permainan Tabung Pintar di Taman kanak-Kanak Negeri Pembina Lubuk Basung. Permasalahan yang dibahas kemampuan mengenal konsep bilangan pada anak belum berkembang sehingga dilakukan tindakan kelas permainan tabung pintar dengan hasil kemampuan berhitung anak dapat ditingkatkan.

\section{KESIMPULAN}

Berdasarkan hasil penelitian dan pembahasan yang dipaparkan sebelumnya, dapat disimpulkan bahwa: 1) Terjadi peningkatan kemampuan membilang 1-10 dengan kemampuan membilang anak mendekati 100\% anak mencapai nilai Berkembang Sangat Baik (BSB); 2) Terjadi peningkatan kemampuan membilang dengan menunjukkan benda ditandai dengan penilaian siklus II sebanyak 93,33\% anak mencapai nilai Berkembang Sangat Baik (BSB), dan 6,67\% Berkembang Sesuai Harapan (BSH); 3) Terjadi peningkatan kemampuan menunjukkan urutan 1-20 kelas B2 ditandai dengan hasil siklus II sebanyak 86,67\% kemampuan anak Berkembang Sangat Baik (BSB), dan 13,33\% Berkembang Sesuai Harapan (BSH). 


\section{DAFTAR PUSTAKA}

Ahmad Susanto, M. P. (2016). Teori belajar dan pembelajaran di sekolah dasar. Kencana.

Alwen Bentri. (2001). Panduan Penyusunan Skripsi Mahasiswa Fakultas Ilmu Pendidikan. Padang : UNP Press Arikunto, S., Suhardjono.,\&Supardi. (2016). Penelitian Tindakan Kelas. Jakarta: PT Bumi Aksara.

Arikunto, S., Suhardjono.,\&Supardi. (2017). Penelitian Tindakan Kelas Edisi Revisi. Jakarta: PT Bumi Aksara

Departemen Pendidikan Nasional. (2003). Didaktik Metodik di taman kanak - kanak. Jakarta : Depdiknas Departemen Pendidikan Nasional. (2007). Didaktik Metodik di taman kanak - kanak. Jakarta : Depdiknas Jamaris. (2006). Perkembangan dan Pengembangan Anak Usia Taman Kanak - Kanak. Jakarta Grasindo Kementerian Pendidikan dan Kebudayaan. (2015). Standar Nasional Pendidikan Anak Usia Dini. Jakarta : Kemendikbud

Khadijah. (2016). Pengembangan Kognitif Anak Usia Dini. Medan: Perdana Mulya Sarana.

Madyawati, Lilis. (2016). Strategi Pengembangan Bahasa Pada Anak. Jakarta: Prenada media Group.

Mutiah, Diana. (2010). Psikologi Bermain Anak Usia Dini. Jakarta : Kencana

Prayitno, Elida. (1995). Perkembangan Anak Usia Dini. Padang : Angkasa Raya.

Rakimahwati. (2009). Pengembangan Kreativitas Anak Usia Dini. Padang: UNP.

Soefandi, I. \& Pramudya, S. A. (2009). Strategi Mengembangkan Potensi Kecerdasan Anak. Jakarta: Bee Media Indonesia.

Sujiono. (2009). Konsep Dasar Pendidikan Anak Usia Dini. Jakarta. Idekf.

Suryana, Dadan. (2013). Pendidikan Anak Usia Dini: Teori Dan Praktik Pembelajaran. Padang: UNP Press.

Suryana, Dadan. (2016). Pendidikan Anak Usia Dini : Stimulasi \& Aspek Perkembangan Anak. Jakarta: Kencana. Susanto, Ahmad. (2011). Perkembangan Anak Usia Dini. Jakarta: Kencana.

Susanto, Ahmad. (2017). Pendidikan Anak Usia Dini (Konsep dan Teori. Jakarta: Kencana

Suyadi\&Ulfah, M. (2013). Konsep Dasar PAUD. Bandung : Rosda.

Srianis, K., Suarni, N. K., Ujianti, P. R., \& Psi, S. (2014). Penerapan Metode Bermain Puzzle Geometri Untuk Meningkatkan Perkembangan Kognitif Anak Dalam Mengenal Bentuk. Jurnal Pendidikan Anak Usia Dini Undiksha, 2(1).

Syaodih, E., \& Agustin, M. (2014). Bimbingan Konseling untuk Anak Usia Dini.

Yulsyofriend. (2009). Permainan Membaca Dan Menulis Anak Usia Dini. Padang: Sukabina Press. 